\title{
Teaching NeuroImages: Adolescent Wallenberg syndrome with overlooked signs
}

\section{Ipsipulsion and ipsilateral facial palsy}

Alexandra Kornbluh, MD, and Jamie-Dawn Twanow, MD

Neurology ${ }^{\circledR}$ 2018;91:e1949-e1950. doi:10.1212/WNL.0000000000006513
Correspondence

Dr. Kornbluh

Alexandra.Kornbluh@

nationwidechildrens.org

Figure $1 \mathrm{MRI}$ findings

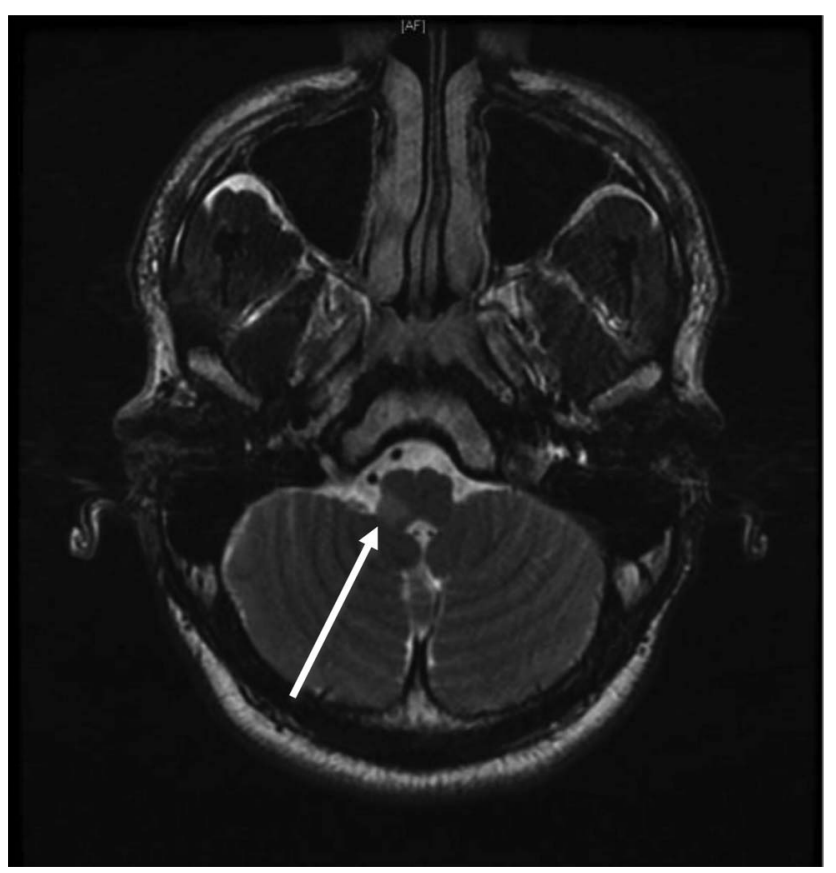

White arrow denotes wedge-shaped focus of restricted diffusion in right dorsal lateral medulla.

A 14-year-old boy presented with vomiting, slurred speech, and leaning rightward. Examination showed dysarthria, right-sided miosis, ptosis, and gaze preference, decreased sensation over the right $\mathrm{V} 2 / \mathrm{V} 3$ region and left shin, right lower facial palsy, rightward tongue deviation, and right-sided dysmetria. Neuroimaging revealed brainstem stroke with vertebral artery dissection (figures 1 and 2). The patient's gaze preference exemplifies ipsipulsion, an often forgotten sign of lateral medullary syndrome resulting from damage to contralateral olivocerebellar pathways that decussate in the medulla. ${ }^{1}$ His ipsilateral facial weakness is due to facial nerve fibers that loop caudally into the medulla and exit at the pontomedullary junction. ${ }^{2}$

\section{MORE ONLINE}

\section{$\rightarrow$ Teaching slides}

links.lww.com/WNL/

A739 
Figure 2 Time-of-flight magnetic resonance angiogram
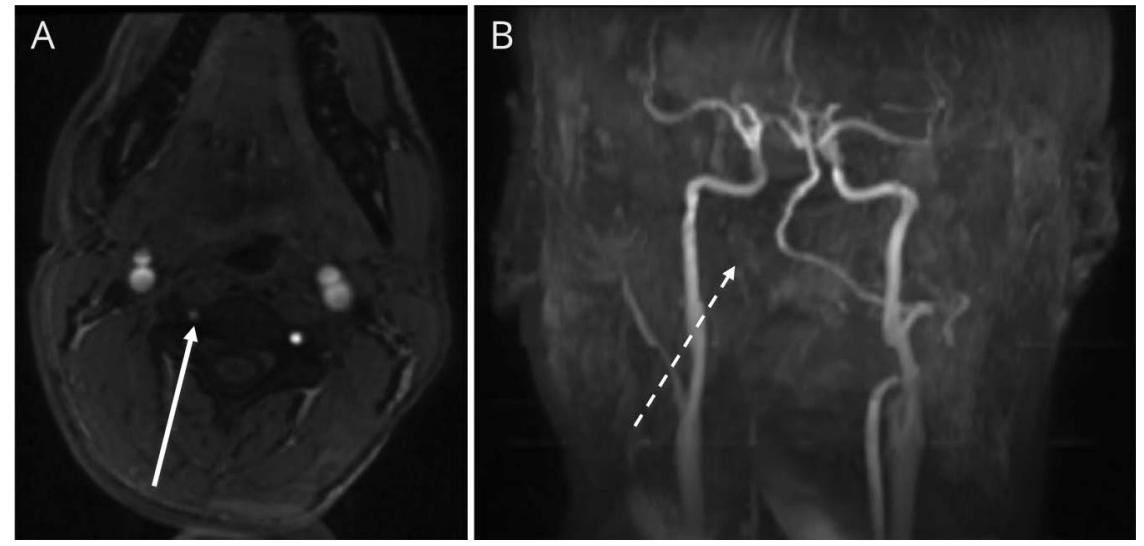

(A) Decreased caliber of the right vertebral artery with irregularity of flow signal (solid arrow) at the C2 level compared with expected flow signal in the left vertebral artery. (B) No significant flow signal in the right vertebral artery intradurally (dashed arrow). Findings suggest right extracranial vertebral artery dissection.

\section{Author contributions}

Dr. Kornbluh: review of case history and EMR documentation, primary research into the literature, choosing appropriate images for figures, primary manuscript author. Dr. Twanow: critical revision of the manuscript for intellectual content, participation in choosing figure images, manuscript supervision.

\section{Study funding}

No targeted funding reported.

\section{Disclosure}

The authors report no disclosures relevant to the manuscript. Go to Neurology.org/N for full disclosures.

\section{References}

1. Paliwal VK, Kumar S, Gupta DK, Neyaz Z. Ipsipulsion: a forgotten sign of lateral medullary syndrome. Ann Indian Acad Neurol 2015;18:284-285.

2. Kim JS. Pure lateral medullary infarction: clinical-radiological correlation of 130 acute, consecutive patients. Brain 2003;126:1864-1872. 


\section{Neurology}

\section{Teaching NeuroImages: Adolescent Wallenberg syndrome with overlooked signs: Ipsipulsion and ipsilateral facial palsy}

Alexandra Kornbluh and Jamie-Dawn Twanow

Neurology 2018;91;e1949-e1950

DOI 10.1212/WNL.0000000000006513

\section{This information is current as of November 12, 2018}

Updated Information \& Services

References

Subspecialty Collections

Permissions \& Licensing

Reprints including high resolution figures, can be found at: http://n.neurology.org/content/91/20/e1949.full

This article cites 2 articles, 0 of which you can access for free at: http://n.neurology.org/content/91/20/e1949.full\#ref-list-1

This article, along with others on similar topics, appears in the following collection(s):

All Cerebrovascular disease/Stroke

http://n.neurology.org/cgi/collection/all_cerebrovascular_disease_strok

Childhood stroke

http://n.neurology.org/cgi/collection/childhood_stroke

Clinical neurology examination

http://n.neurology.org/cgi/collection/clinical_neurology_examination Infarction

http://n.neurology.org/cgi/collection/infarction

Information about reproducing this article in parts (figures,tables) or in its entirety can be found online at:

http://www.neurology.org/about/about_the_journal\#permissions

Information about ordering reprints can be found online:

http://n.neurology.org/subscribers/advertise

Neurology ${ }^{\circledR}$ is the official journal of the American Academy of Neurology. Published continuously since 1951, it is now a weekly with 48 issues per year. Copyright @ 2018 American Academy of Neurology. All rights reserved. Print ISSN: 0028-3878. Online ISSN: 1526-632X.

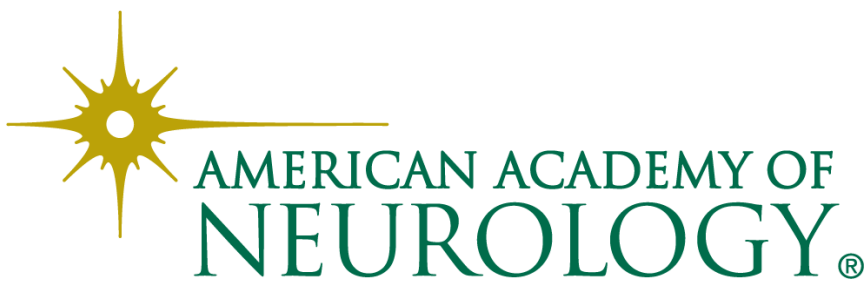

